\title{
MICROBIOLOGICAL QUALITY ATTRIBUTES OF NILE PERCH LATES NILOTICUS FISH FILLETS TREATED WITH AQUEOUS EXTRACT OF LEPIDIUM SATIVUM L. CRESS SEEDS
}

\author{
ABDEL AZIZ, HANAA A. and ATEF S.A. OSHEBA \\ Meat and Fish Technology Research Department, Food Technology Research Institute, \\ ARC, Giza, Egypt \\ (Manuscript received 2 April 2012)
}

\begin{abstract}
The antimicrobial activity of the aqueous and methanol extracts of Lepidium sativum cress seeds at various concentrations (1,2 and $3 \%)$ against four strains of gramnegative bacteria including Escherichia coli, E. coli 157, Salmonella typhimurium and Kelbsiella pneumonia, four strains of gram-positive bacteria including Staphylococcus aureus, Bacillus subtilus, Bacillus megaterium and Listeria moncytogenes serotype, two yeasts including Candida albicans and Sacchromyces cerevisiae and one fungi (Aspergillus niger) was assessed. Also, the effect of spraying with aqueous cress seeds extract on microbiological attributes and shelf life of Nile perch fish fillets was also studied. The results indicated that all concentrations of aqueous extract were active against all tested microorganisms except Klebsiella pneumonae. On the other hand, the methanol Lepidium sativum extract at 1 and $2 \%$ had no effect on the growth of all gram-negative bacteria. Meanwhile, the above mentioned concentrations of methanol extract had detectable effects on the gram-positive bacteria, yeasts and fungi. Also, the antimicrobial effect of aqueous and methanol extracts was increased with increasing the concentrations. The results also showed that the distilled water was better than methanol for extracting antimicrobial substances from this seeds. Therefore, spraying of Nile perch fish fillets with various concentrations $(1,2$ and $3 \%$ ).of the aqueous extract was the suggested treatment to reduce the microbial load and extend the shelf life.
\end{abstract}

\section{INTRODUCTION}

Nile perch Lates niloticus is the most important commercial fish species in Egypt, it is often displayed for sale to consumers' in the form of fillets. According to professionals in fish sales, the consumption of fillets will continue to increase in the future, due to new lifestyle habits as people have less time to cook, and the younger generations' increasing habit of consuming prepared products (GIAUC, 2006). Fish is an important source of high-quality proteins for humans (Tidwell and Allan, 2001). However, it is highly susceptible to both microbiological and chemical deterioration due to its high water activity, neutral $\mathrm{pH}$, relatively large quantities of free amino acids 
and presence of autolytic enzymes (Jeyasekaran, et. al., 2006). Cold storage and freezing are the normally employed methods for fish preservation, but they do not completely inhibit the quality deterioration of fish (Jeon et. al., 2002).

Many plants have been used because of their antimicrobial traits, which are due to compounds synthesized in the secondary metabolism of the plant. These products are known by their active substances, for example, phenolic compounds, which are part of essential oils, tannins, terpenoids, alkaloids, and flavonoids. These metabolites have been found in vitro to have antimicrobial properties. The antimicrobial compounds produced by plants are active against plant and human pathogenic microorganisms. Several reports are available in literature regarding the antimicrobial activity of plant crude extracts and the procedure for the bioassayguided fractionation to yield active principles from these plants (Parekh and Chanda, 2008)

Lepidium sativum L., (LS) cress, locally known as Rashad, is a fast-growing annual tall herb with an erect stem belonging to the Brassicaceae family. Lepidium sativum plant and seeds are considered one of the popular medicinal herbs used in many countries. A number of recent studies pointed out the traditional uses of Lepidium sativum seeds extract in controlling many clinical problems (Eddouks et. al., 2002). Also, in controlling of many microorganisms, it was found that petroleum ether, methanol and water extracts of Lepidium sativum seeds had antimicrobial activity against five bacterial strains namely Staphylococcus aureus, Escherichia coli, Klebsiella pneumonae, Proteus vulgaris, Pseudomonas aeruginosa and one yeast (Candida albicans) using 2.5, 5 and 10\% concentrations (Adam et. al., 2011). They showed that the petroleum ether was the best solvent for extracting antimicrobial substances from this plant compared to methanol and water. Also Akrayi and Tawfeeq (2012) studied the antibacterial effect of ethanolic and aqueous extracts of Lepidium sativum against some gram negative and gram positive bacteria such as (Klebsiella pneumoniae, Proteus, Pseudomonas aeruginosa, Staphylococcus aureus and Streptococcus mutans). The results revealed that, the extracts had an inhibitory effect on all the bacteria under study except Klebsiella pneumoniae.

The objectives of this study were to estimate the antimicrobial activity of methanol and aqueous extracts of Egyptian cress seeds at various concentrations ( 1 , 2 and 3\%) against numerous microorganisms using the Disc Assay Procedure, and then evaluate the effect of spraying with above mentioned concentrations of aqueous cress seed extract on the microbiological quality attributes and shelf life of Nile perch 
fish fillets during displaying under conditions resembling that in the fish market ( 6 hrs) at room temperature and through cold storage at $4 \pm 1^{\circ} \mathrm{C}$ up to spoilage.

\section{MATERIALS AND METHODS}

\section{Materials}

Fish

Fresh Nile perch fish Lates niloticus was purchased from the private sector shop in the local fishery market at Giza, Egypt. It was transferred to the laboratory of Meat and Fish Res. Dept., FTRI using an ice box within 45 min.

\section{Cress seeds}

Cress Lepidium sativum seeds were obtained from a local market in Giza, Egypt.

\section{Bacterial strains}

Eight strains of bacteria representing gram- negative bacteria including Escherichia coli, NRRL B-210, E coli 0157, , Salmonella typhimurium, and Kelbsiella pneumonnia ATTCC700603 and gram - positive bacteria including Staphylococcus aureus, NRRL B-313, Bacillus subtilus NRRL B-543, Bacillus megaterium NRRL B-1366 and Listeria moncytogenes serotype NRRL 3105 in addition to two yeast including Candida albicans NRRL Y-477 and Sacchromyces cerevisiae NRRL Y-12632 and one fungi (Aspergillus niger NRRL-3) were obtained from Department of Chemistry of Natural and Microbial product, National Research Center. These microorganisms were kept in our laboratory in the frozen state until used.

\section{Methods}

\section{Preparation of aqueous and methanol cress seeds extracts}

Various concentrations of the aqueous and methanol extracts (1,2 and $3 \%)$ were prepared as the fowling: The aqueous extracts were prepared by boiling 1, 2 and $3 \mathrm{~g}$ of dried powdered seeds of L. sativum separately in distilled water for $10 \mathrm{~min}$ and left for $15 \mathrm{~min}$ to infuse. Thereafter, the extracts were cooled and filtered to remove particulate matter (Patel et. al., 2009). For the methanol extracts, the cress seeds powder was steeped in methanol for 3 days and then filtered using filter paper (Whatman No.1) and centrifuged at $3000 \mathrm{rpm}$ for 10 minutes. The supernatants were collected separately and stored in sterile bottles and stored at $4 \pm 1^{\circ} \mathrm{C}$ (Akrayi and Tawfeeq, 2012).

\section{Fish fillets and treatments}

Fish were washed with tap water, beheaded, gutted, washed again with tap water, and then filleted. The fillets were divided to four groups. The first group left without any treatment, meanwhile, other groups (second, third and fourth) were 
sprayed with various concentrations of aqueous cress seeds extract (1, 2 and $3 \%)$, respectively. All groups were kept at room temperature up to $6 \mathrm{hrs}$, after that stored in refrigerator at $4 \pm 1^{\circ} \mathrm{C}$ up to spoilage. Analyses were carried out at zero, $6 \mathrm{hrs}$ at room temperature and 3, 6, 9 and 12 day of refrigerated storage.

\section{Microbiological methods}

\section{Determination of antimicrobial activity of different concentrations of aqueous and methanol cress seeds extracts}

All microbial cultures were taken out of the freezer and kept at room temperature for one hour in order to get thawed. Two loopfuls of each culture were transferred aseptically into sterile agar slants specific for each organism. They were incubated at $37^{\circ} \mathrm{C} / 24 \mathrm{hr}$ for bacteria strains and at $25^{\circ} \mathrm{C} / 4$ days for yeast and fungi strains, then, they were kept in the refrigerator until used. To start work, cultures were activated by transferring two loopfuls from each agar slant into $9 \mathrm{ml}$ of the broth specific for each microorganism. All inoculated broth media were incubated at $37^{\circ} \mathrm{C} /$ $24 \mathrm{hr}$ for bacteria strains and at $25^{\circ} \mathrm{C} / 4$ days for yeast and fungi strains, $0.1 \mathrm{ml}$ of each culture was inoculated into $9 \mathrm{ml}$ of its respective broth medium and incubated at $37^{\circ} \mathrm{C} / 24 \mathrm{hr}$ for bacteria strains and at $25^{\circ} \mathrm{C} / 4$ days for yeast and fungi strains. The count of each culture was determined, followed by applying the Paper Disc Plate method as reported by Loo et. al., (1945).

\section{Paper Disc Plate method}

$1.0 \mathrm{ml}$ of the above incubated culture (average counts for all strains $1.0-7.0$ $\left.\times 10^{6} \mathrm{cfu} / \mathrm{ml}\right)$ was inoculated into $15 \mathrm{ml}$ of sterile agar $\left(45-50^{\circ} \mathrm{C}\right)$ specific for each organism. The inoculated agar was poured aseptically into sterile Petri plates. The agar was allowed to solidify. A sterile filter paper of $0.5 \mathrm{~cm}$ diameters was saturated with each concentration of both aqueous and methanol cress seed extracts for $30 \mathrm{sec}$, and then it was placed in the center of each Petri plate containing the inoculated specific agar. The plates were incubated at $37^{\circ} \mathrm{C} / 24 \mathrm{hr}$ for bacteria strains and at $25^{\circ} \mathrm{C} / 4$ days for yeast and fungi strains. The diameter of each inhibition zone was determined in $\mathrm{mm}$.

\section{Microbial load of fish fillets}

\section{Sample preparation}

Ten gram of a representative fish fillets sample were mixed with $90 \mathrm{ml}$ of sterile peptone water (10 g peptone / $1 \mathrm{~L}$ distilled water) in a blender, under sterile conditions, to give $1 / 10$ dilution. Serial dilutions were prepared to be used for counting total bacteria count, coliform bacteria, proteolytic bacteria, psychrophilic bacteria, Staphylococcus aureus and yeast and mold counts. 


\section{Bacteriological methods}

Total bacterial count (TBC), Staphylococcus aureus, coilform bacteria, proteolytic bacteria, Psychrophilic and yeast \& mold counts of fish were determined by using nutrient agar, Baird-parker, MacConkey, nutrient agar medium plus $10 \%$ sterile skim milk, nutrient agar and Potato dextrose agar media, respectively according to the procedures described by Difco Manual (1984). Incubations were carried out at $37^{\circ} \mathrm{C} /$ $48 \mathrm{hrs}$ for TBC, at $37^{\circ} \mathrm{C} / 24 \mathrm{hrs}$ for Staphylococcus aureus and coliform bacteria, at $30^{\circ} \mathrm{C}$ for 3 days for proteolytic bacteria, at $7{ }^{\circ} \mathrm{C} / 10$ days for psychrophilic and $25^{\circ} \mathrm{C} /$ 5 days for yeasts $\&$ molds counts.

\section{RESULTS AND DISCUSSION}

\section{Antimicrobial effect of aqueous and methanol extracts of cress seeds}

The antimicrobial effect of aqueous and methanol extracts of cress seeds at various concentrations (1, 2 and 3\%) against four strains of gram negative bacteria, Escherichia coli, Escherichia coli 157, Salmonella typhimurium, Klebsiella pneumonae, four strains of gram positive bacteria, Staphylococcus aureus, Bacillus subtilus, Bacillus megaterium, Listeria moncytogenes and two yeasts strains, Candida albicans, Sacchromyces cerevisiae as well as one fungi, Aspergillus niger are summarized in Table (1). The results indicated that various concentrations (1, 2, and 3\%) of aqueous extract of Lepidium sativum were active against all tested microorganisms except Klebsiella pneumonae, which was high resistant for the above mentioned concentrations, this may be attributed to the presence of a capsule in $K$. pneumoniae structure that protects it from the effect of plant extract or prevents the entrance of these extracts to inner of the cell (Akrayi and Tawfeeq, 2012). Also, the inhibition zone for all studied microorganisms was increased with the increasing the concentrations of aqueous Lepidium sativum extract. This might be attributed to the presence of some chemical components which had antimicrobial activity such as flavonoids, alkaloids, strerols and/or triterpens, tannins and glucosinolaters (Brotonagoro and Wiharti, 2001).

The concentrations of methanol Lepidium sativum extracts $(1,2$, and $3 \%)$ showed different effects against tested microorganisms, whereas, 1 and $2 \%$ concentrations had no effect on the growth of all gram negative bacteria. On the other hand, the same concentrations had detectable effects on gram positive bacteria, yeast and fungi consequently the latter microorganisms were more sensitive than gram negative bacteria. Also, from the same Table, it could be observed that the highest inhibitory action of methanol Lepidium sativum extract against all gram 
negative bacteria strains except Klebsiella pneumonae was recorded at $3 \%$ concentration.

Table 1. Antimicrobial activity as diameters inhibition zone $(\mathrm{mm})$ of aqueous and methanol extracts of cress seeds at various concentrations

\begin{tabular}{|l|c|c|c|c|c|c|}
\hline \multirow{2}{*}{ Tested Organisms } & \multicolumn{3}{|c|}{ Aqueous extract } & \multicolumn{3}{c|}{ Methanol extract } \\
\cline { 2 - 7 } & $\mathbf{1 . 0} \%$ & $\mathbf{2 . 0} \%$ & $\mathbf{3 . 0} \%$ & $\mathbf{1 . 0} \%$ & $\mathbf{2 . 0} \%$ & $\mathbf{3 . 0} \%$ \\
\hline Escherichia coli, & 9 & 11 & 14 & - & - & 9 \\
\hline Escherichia coli 157 & 8 & 10 & 13 & - & - & 7 \\
\hline Salmonella typhimurium & 11 & 14 & 15 & - & - & 5 \\
\hline Kelbsiella pneumonnia & - & - & - & - & - & - \\
\hline Staphylococcus aureus & 15 & 16 & 18 & 7 & 8 & 10 \\
\hline Bacillus subtilus & 12 & 14 & 17 & 7 & 9 & 12 \\
\hline Bacillus megaterium & 9 & 11 & 15 & 5 & 7 & 10 \\
\hline Listeria moncytogenes & 14 & 16 & 17 & 9 & 11 & 13 \\
\hline Candida albicans & 9 & 11 & 14 & 5 & 9 & 11 \\
\hline Sacchromyces cerevisiae & 12 & 15 & 18 & 8 & 10 & 15 \\
\hline Aspergillus niger & 10 & 14 & 16 & 6 & 8 & 12 \\
\hline
\end{tabular}

From the above mentioned results, it could be illustrated that the antimicrobial effects of aqueous and methanol Lepidium sativum extracts were more pronounced on gram positive bacteria than gram negative bacteria. In this concern, several studies showed that gram negative bacteria had higher resistance to plant extracts than gram positive bacteria (Kudi et. al., 1999 and Palombo and Semple, 2001). This can be as a result of the variation in the cell wall structures of gram positive bacteria and gram negative bacteria. More specifically, gram negative bacteria have an outer membrane that is composed of high density lipopolysaccharides that serves as a barrier to many environmental substrances including antibiotics (Palombo and Semple, 2001). The results also showed that the distilled water was the best solvent for extracting antimicrobial substances from Lepidium sativum seeds compared to methanol. This was shown by its high inhibitory effect against all tested microorganisms at the studied concentrations. These results were in agreement with findings of Adam et. al. (2011) and Akrayi and Tawfeeq (2012). 


\section{Microbial load of Nile perch fish fillets as affected by various concentrations of aqueous seeds extract}

\section{1- Total bacterial count}

The data presented in Table (2) shows total bacterial count (TBC) of fish fillets treated with various concentrations of aqueous cress seeds extract $(0.0,1.0,2.0$ and $3.0 \%$ ) during storage at room temperature up to $6 \mathrm{hrs}$ and cold-storage at $4 \pm 1^{\circ} \mathrm{C}$ up to spoilage. It was observed that the initial total bacterial count of fresh fish fillets was $5.1 \times 10^{3} \mathrm{cfu} / \mathrm{g}$ for control (untreated), this value slightly decreased to $2.48 \times 10^{3}, 2.43 \times 10^{3}$ and $1.80 \times 10^{3} \mathrm{cfu} / \mathrm{g}$ after $30 \mathrm{~min}$ from treatment of Nile perch fillets by spraying with aqueous cress seeds extract at 1, 2 and $3 \%$ concentrations, respectively. After leave the fish fillets either untreated or treated for $6 \mathrm{hrs}$ at room temperature, it was found that the total bacterial count increased markedly for untreated fillets than treated fillets, this may be due to the cress seeds contain some chemical compounds which had antimicrobial effect as reported by AlYahya et. al., (1994) and Adam et. al., (2011).

With cold storage period at $4 \pm 1^{\circ} \mathrm{C}$, the total bacterial count showed an increasing trend for all samples. The increase was higher for untreated sample compared to treated samples. This indicates the effectiveness of aqueous cress seeds extract for inhibiting the growth of microorganisms. Also, TBC of fish fillets was decreased with increasing the aqueous cress seeds extract concentrations at any time of cold-storage. The control sample (untreated fillets) reached $5.44 \times 10^{6} \mathrm{cfu} / \mathrm{g}$ in the $6^{\text {th }}$ day of cold-storage. It exceeds the maximal permissible limit of $10^{6} \mathrm{cfu} / \mathrm{g}$ for the total bacterial count in chilled-fish (Egyptian Standard, 2005), while the TBC of treated samples reached about $10^{6}$ in the $12^{\text {th }}$ day of cold-storage. Therefore, the treatment of Nile perch fish fillets with aqueous cress seeds extract was more effective to maintain high microbiological quality and extending the shelf life during the displaying of fillets in the fish markets under normal conditions and during coldstorage. 
Table 2. Total bacterial count (cfu / g) of Nile perch fish fillets treated with various concentrations of aqueous cress seeds extract $(0.0,1.0,2.0$ and $3.0 \%$ ) during storage at room temperature up to $6 \mathrm{hrs}$ and at $4^{\circ} \mathrm{C}$ up to spoilage

\begin{tabular}{|c|c|c|c|c|}
\hline Treatments & Control & $\mathbf{1 . 0} \%$ & $\mathbf{2 . 0} \%$ & $\mathbf{3 . 0} \%$ \\
\hline Ztorage & & & & \\
\hline Zero time & $5.1 \times 10^{3}$ & $2.48 \times 10^{3}$ & $2.43 \times 10^{3}$ & $1.80 \times 10^{3}$ \\
\hline 6 hrs & $2.25 \times 10^{4}$ & $8.89 \times 10^{3}$ & $6.15 \times 10^{3}$ & $3.51 \times 10^{3}$ \\
\hline 3 days & $2.88 \times 10^{5}$ & $6.54 \times 10^{4}$ & $1.0 \times 10^{4}$ & $5.5 \times 10^{3}$ \\
\hline 6 days & $5.44 \times 10^{6}$ & $1.06 \times 10^{5}$ & $8.11 \times 10^{4}$ & $6.98 \times 10^{4}$ \\
\hline 9 days & $1.45 \times 10^{7}$ & $9.21 \times 10^{5}$ & $5.05 \times 10^{5}$ & $2.42 \times 10^{5}$ \\
\hline $\mathbf{1 2}$ days & $7.65 \times 10^{7}$ & $6.45 \times 10^{6}$ & $3.63 \times 10^{6}$ & $1.04 \times 10^{6}$ \\
\hline
\end{tabular}

\section{2- Coilform bacteria}

Data in Table (3) shows coilform bacteria counts of fish fillets treated with various concentrations of aqueous cress seeds extract (0.0, 1.0, 2.0 and $3.0 \%$ ) during storage at room temperature up to $6 \mathrm{hrs}$ and at $4 \pm 1^{\circ} \mathrm{C}$ up to spoilage. At zero time and after 6 hrs of storage at room temperature, it was noticed that coilform bacteria appeared in control and fish fillets treated with $1.0 \%$ aqueous cress seeds extract, but the latter sample had lower coilform bacteria than control (untreated), meanwhile coilform bacteria not detected in fish fillets treated with 2 and $3 \%$ aqueous cress seeds extracts at zero time and during cold-storage, this indicates that the treatment of fish fillets with $1.0 \%$ aqueous cress seeds extract led to partially inhibition for coilform bacteria, while concentrations 2.0 and $3.0 \%$ had complete inhibition for this bacteria, this may be due to 2 and $3 \%$ of aqueous cress seeds extracts had higher some chemical compounds having antimicrobial activity than $1 \%$ concentration. During cold-storage at $4 \pm 1^{\circ} \mathrm{C}$, coilform bacterial count increased for both control and that treated with $1.0 \%$ aqueous cress seeds extract, but the rate of increase was lower for the samples treated by aqueous cress seeds extract, this may be due to that the cress seeds have antimicrobial activity as reported by Al-Yahya et. al., (1994) and Adam et. al., (2011). The control sample reached $3.34 \times 10^{3} \mathrm{cfu} / \mathrm{g}$ in the $9^{\text {th }}$ day of cold-storage. Meanwhile fish fillets treated with $1.0 \%$ not reached $10^{3}$ at the same day, this may be attributed to the inhibitory effect of cress seeds extract. 
Table 3. Coilform bacteria (cfu / g) of Nile perch fish fillets treated with various concentrations of aqueous cress seeds extract $(0.0,1.0,2.0$ and $3.0 \%$ ) during storage at room temperature up to $6 \mathrm{hrs}$ and at $4^{\circ} \mathrm{C}$ up to spoilage

\begin{tabular}{|c|c|c|c|c|}
\hline Treatments & Control & $\mathbf{1 . 0} \%$ & $\mathbf{2 . 0} \%$ & $\mathbf{3 . 0} \%$ \\
\hline Zero time & $3.5 \times 10^{1}$ & $2.5 \times 10^{1}$ & $\mathrm{ND}$ & $\mathrm{ND}$ \\
\hline $\mathbf{6}$ hrs & $6.5 \times 10^{1}$ & $4.0 \times 10^{1}$ & $\mathrm{ND}$ & $\mathrm{ND}$ \\
\hline $\mathbf{3}$ days & $1.28 \times 10^{2}$ & $8.5 \times 10^{1}$ & $\mathrm{ND}$ & $\mathrm{ND}$ \\
\hline $\mathbf{6}$ days & $6.3 \times 10^{2}$ & $1.27 \times 10^{2}$ & $\mathrm{ND}$ & $\mathrm{ND}$ \\
\hline $\mathbf{9}$ days & $3.34 \times 10^{3}$ & $8.25 \times 10^{2}$ & $\mathrm{ND}$ & $\mathrm{ND}$ \\
\hline $\mathbf{1 2}$ days & $5.12 \times 10^{3}$ & $2.14 \times 10^{3}$ & $\mathrm{ND}$ & $\mathrm{ND}$ \\
\hline
\end{tabular}

ND $=$ Not Detected

\section{3- Proteolytic bacteria}

Proteolytic bacterial counts of fish fillets treated with various concentrations of aqueous cress seeds extract $(0.0,1.0,2.0$ and $3.0 \%)$ during storage at room temperature up to $6 \mathrm{hrs}$ and at $4 \pm 1^{\circ} \mathrm{C}$ up to spoilage are presented in Table (4). At zero time, it was observed that proteolytic bacteria appeared in all fish fillets samples, but the counts in treated samples with various concentrations were slightly lower than control sample, this reflex the inhibitory effect of aqueous cress seeds extract. The population of proteolytic bacteria was decrement with increment aqueous cress seeds extract concentrations not only at zero time, but also at any time of cold storage. From the same Table, it could be noticed that, proteolytic bacteria grew fast in control sample compared to fish fillets treated with various concentrations of aqueous cress seeds extract especially (2.0 and $3.0 \%$ ) during storage. Proteolytic bacteria of control sample rapidly increased from the initial count $9.5 \times 10^{1}$ to $4.96 \times 10^{2} \mathrm{cfu} / \mathrm{g}$ by the end of displaying time at room temperature up to $6 \mathrm{hrs}$ and reached $9.05 \times 10^{5} \mathrm{cfu} /$ $\mathrm{g}$ by the end of cold storage ( $12^{\text {th }}$ day). On the other hand, treatment of fish fillets with various concentrations of aqueous cress seeds extract lowered the population of proteolytic bacteria. The percentage of decrement after $6 \mathrm{hrs}$ at room temperature was $64.71,81.85$ and $86.89 \%$ of fish fillets treated with concentrations of $1.0,2.0$ and $3.0 \%$ of aqueous cress extracts respectively, compared with control sample. These percentages were increased to $91.85,96.06$ and $97.81 \%$, respectively when compared with control sample at the end of cold storage. 
Table 4. Proteolytic bacteria (cfu / g) of Nile perch fish fillets treated with various concentrations of aqueous cress seeds extract $(0.0,1.0,2.0$ and $3.0 \%$ ) during storage at room temperature up to $6 \mathrm{hrs}$ and at $4^{\circ} \mathrm{C}$ up to spoilage

\begin{tabular}{|c|c|c|c|c|}
\hline Treatments & Control & $\mathbf{1 . 0} \%$ & $\mathbf{2 . 0} \%$ & $\mathbf{3 . 0} \%$ \\
\hline Zero time & $9.5 \times 10^{1}$ & $6.0 \times 10^{1}$ & $4.5 \times 10^{1}$ & $3.0 \times 10^{1}$ \\
\hline $\mathbf{6}$ hrs & $4.96 \times 10^{2}$ & $1.75 \times 10^{2}$ & $9.0 \times 10^{1}$ & $6.5 \times 10^{1}$ \\
\hline 3 days & $2.76 \times 10^{3}$ & $8.17 \times 10^{2}$ & $4.3 \times 10^{2}$ & $2.03 \times 10^{2}$ \\
\hline 6 days & $1.65 \times 10^{4}$ & $6.85 \times 10^{3}$ & $2.7 \times 10^{3}$ & $9.45 \times 10^{2}$ \\
\hline 9 days & $8.98 \times 10^{4}$ & $2.04 \times 10^{4}$ & $8.62 \times 10^{3}$ & $3.91 \times 10^{3}$ \\
\hline 12 days & $9.05 \times 10^{5}$ & $7.38 \times 10^{4}$ & $3.57 \times 10^{4}$ & $1.98 \times 10^{4}$ \\
\hline
\end{tabular}

\section{4- Staphylococcus aureus}

Data presented in Table (5) show Staphylococcus aureus counts of fish fillets treated with various concentrations of aqueous cress seeds extract $(0.0,1.0,2.0$ and $3.0 \%$ ) during storage at room temperature up to $6 \mathrm{hrs}$ and during cold storage at $4 \pm 1^{\circ} \mathrm{C}$. up to spoilage. From these results it could be noticed that, Staphylococcus aureus appeared in all fish fillets samples except fish fillets treated with $3 \%$ aqueous cress seeds extract at zero time. The initial Staphylococcus aureus count of the untreated sample was $6.5 \times 10^{1} \mathrm{cfu} / \mathrm{g}$, which reduced to $2.5 \times 10^{1}$ and $2.0 \times 10^{1} \mathrm{cfu}$ / g for samples treated with 1 and $2 \%$ aqueous cress seeds extract. Staphylococcus aureus not detected in fish fillets treated with $3 \%$ aqueous cress seeds extract either at zero time or along cold storage period. With advancement of storage, the counts of Staphylococcus aureus showed an increasing trend. The increase was higher for control compared to treated samples. This indicates the effectiveness of aqueous cress seeds extract in inhibiting the growth of Staphylococcus aureus. Also the counts of Staphylococcus aureus in fish fillets were decreased with increasing with of aqueous cress seeds extract concentrations at any time of storage. The control sample reached $3.18 \times 10^{3} \mathrm{cfu} / \mathrm{g}$ in the $9^{\text {th }}$ day of cold-storage, it was exceed the maximal permissible limit of $10^{3} \mathrm{cfu} / \mathrm{g}$ for Staphylococcus aureus in chilled fish (Egyptian Standard, 2005), while Staphylococcus aureus of fish fillets treated with 1 and $2 \%$ aqueous cress seeds extract $\left(9.03 \times 10^{2}\right.$ and $5.73 \times 10^{2} \mathrm{cfu} / \mathrm{gm}$, respectively) was not exceeded the maximal permissible limit. Moreover, at the end of cold storage $\left(12^{\text {th }}\right.$ day), concerning Staphylococcus aureus, fish fillets which treated 
with $2 \%$ aqueous cress seeds extract, not exceeded the maximal permissible limit which reported by (Egyptian standard, 2005).

Table 5. Staphylococcus aureus (cfu / g) of Nile perch fish fillets treated with various concentrations of aqueous cress seeds extract $(0.0$, 1.0, 2.0 and $3.0 \%$ ) during storage at room temperature up to 6 hrs and at $40 \mathrm{C}$ up to spoilage

\begin{tabular}{|c|c|c|c|c|}
\hline Storage & Control & $\mathbf{1 . 0} \%$ & $\mathbf{2 . 0} \%$ & $\mathbf{3 . 0} \%$ \\
\hline Zero time & $6.5 \times 10^{1}$ & $2.5 \times 10^{1}$ & $2.0 \times 10^{1}$ & $\mathrm{ND}$ \\
\hline 6 hrs & $8.5 \times 10^{1}$ & $3.5 \times 10^{1}$ & $3.5 \times 10^{1}$ & $\mathrm{ND}$ \\
\hline 3 days & $3.4 \times 10^{2}$ & $9.0 \times 10^{1}$ & $5.0 \times 10^{1}$ & $\mathrm{ND}$ \\
\hline 6 days & $9.65 \times 10^{2}$ & $3.55 \times 10^{2}$ & $1.62 \times 10^{2}$ & $\mathrm{ND}$ \\
\hline 9 days & $3.18 \times 10^{3}$ & $9.03 \times 10^{2}$ & $5.73 \times 10^{2}$ & $\mathrm{ND}$ \\
\hline $\mathbf{1 2}$ days & $7.0 \times 10^{3}$ & $2.41 \times 10^{3}$ & $8.97 \times 10^{2}$ & $\mathrm{ND}$ \\
\hline
\end{tabular}

\section{5- Psychrophilic bacteria}

Microorganisms which grow in food at refrigeration temperature have usually been called psychrophilic. The gram- negative psychrophilic bacteria are the major group of microorganisms responsible for spoilage of aerobically stored fresh fish at chilled temperatures (Ibrahim, 2007). Psychrophilic bacteria of fish fillets treated with various concentrations of aqueous cress seeds extract (0.0, 1.0, 2.0 and $3.0 \%)$ during storage at room temperature up to $6 \mathrm{hrs}$ and at $4 \pm 1^{\circ} \mathrm{C}$. up to spoilage are presented in Table (6). The initial psychrophilic bacteria count of control was $6.17 \times$ $10^{2} \mathrm{cfu} / \mathrm{g}$ which reduced to $2.61 \times 10^{2}, 7.0 \times 10^{1}$ and $5.5 \times 10^{1} \mathrm{cfu} / \mathrm{g}$ for fish fillets treated with 1, 2 and $3 \%$ aqueous cress seeds extract, respectively. The above mentioned initial psychrophilic bacteria count was lower than the values reported by Ojagh et. al (2010) for fresh trout fillet which found to be $3.85 \log _{10} \mathrm{cfu} / \mathrm{g}$.

During cold-storage, psychrophilic bacteria count gradually increased for all fish fillets samples, but the rate of increase was lower for the samples treated by aqueous cress seeds extract than control sample. This may be due to the cress seeds contain some photochemical compounds which have antimicrobial activity as reported by Al-Yahya et. al., (1994) and Adam et. al., (2011). The data of psychrophilic bacteria of fish fillets as affected by using various concentrations of aqueous cress seeds extract during storage period is found in Table (6). From the results, it could be observed that, psychrophilic bacteria of control reached1.87 $\times 10^{6} \mathrm{cfu} / \mathrm{g}$ by the end of cold storage $\left(12^{\text {th }}\right.$ day), meanwhile, reached $5.18 \times 10^{5}, 8.65 \times 10^{4}$ and $2.53 \times 10^{4}$ cfu / $\mathrm{g}$ for fish fillets treated with 1, 2 and $3 \%$ aqueous cress seeds extract. These 
results are partially in agreement with those obtained by Hernandez, et. al., (2009) who found that psychrophilic aerobic count in meagre fillets was $2.82 \log \mathrm{cfu} / \mathrm{g}$ at zero time and reached to $10.8 \log$ cfu / $\mathrm{g}$ after 18 days in ice storage.

Table 6. Psychrophilic bacteria (cfu / g) of Nile perch fish fillets treated with various concentrations of aqueous cress seeds extract $(0.0$, $1.0,2.0$ and $3.0 \%$ ) during storage at room temperature up to 6 hrs and at $4^{\circ} \mathrm{C}$ up to spoilage

\begin{tabular}{|c|c|c|c|c|}
\hline Storage & Control & $\mathbf{1 . 0} \%$ & $\mathbf{2 . 0} \%$ & $\mathbf{3 . 0} \%$ \\
\hline Zero time & $6.17 \times 10^{2}$ & $2.61 \times 10^{2}$ & $7.0 \times 10^{1}$ & $5.5 \times 10^{1}$ \\
\hline $\mathbf{6}$ hrs & $8.19 \times 10^{2}$ & $4.96 \times 10^{2}$ & $1.10 \times 10^{2}$ & $9.0 \times 10^{1}$ \\
\hline $\mathbf{3}$ days & $5.17 \times 10^{3}$ & $1.27 \times 10^{3}$ & $8.5 \times 10^{2}$ & $4.61 \times 10^{2}$ \\
\hline $\mathbf{6}$ days & $6.75 \times 10^{4}$ & $9.85 \times 10^{3}$ & $3.76 \times 10^{3}$ & $1.21 \times 10^{3}$ \\
\hline 9 days & $4.79 \times 10^{5}$ & $8.12 \times 10^{4}$ & $2.68 \times 10^{4}$ & $8.5 \times 10^{3}$ \\
\hline $\mathbf{1 2}$ days & $1.87 \times 10^{6}$ & $5.18 \times 10^{5}$ & $8.65 \times 10^{4}$ & $2.53 \times 10^{4}$ \\
\hline
\end{tabular}

\section{6- Yeast sand molds counts}

All fish fillets samples whether the untreated or treated with various concentrations of aqueous cress seeds extract $(0.0,1.0,2.0$ and $3.0 \%)$ were completely free from yeasts sand molds either at zero time or during storage period.

\section{CONCLUSION}

From the above study, it was concluded that the aqueous cress seeds extract with various concentrations (1.0, 2.0 and $3.0 \%$ ) has antimicrobial activity against many microbial strains. Also, treatment of Nile perch fish fillets with this extract led to maintain high microbiological quality and extending the shelf life

\section{REFERENCES}

1. Adam, S.I.Y., S. A. M. Salih. and W.S. Abdelgadir. 2011. In vitro antimicrobial assessment of Lepidium sativum L. seeds extracts. Asian Journal of Medical Sciences, 3(6): 261-266.

2. Akrayi, H.F.S. and J.D. Tawfeeq. 2012. Antibacterial activity of Lepidium sativum and Allium porrum extracts and juices against some gram positive and gram negative bacteria. Medical Journal of Islamic World Academy of Sciences, 20 (1): 10-16. 
3. AL-Yahya, M.A., J.S. Mossa, A.M. Ageel, and S. Rafatullh. 1994. Pharmacological and Safety Evaluation Studies on Lepidium sativum L, Seeds. Phytomedicine, 1:155-9.

4. Brotonegoro, S. and W.Wiharti. 2001. Lepidium sativum L. In: Van Valkenburg, J.L.C.H. and N. Bunyapraphatsara, (Eds.), Plant Resources of South- East Asia No 12 (2): Medicinal and Poisonous Plants. Broun, A.F. and R.E. Massey, 1929. Flora of the Sudan. Wellington House, Buckingham Gate, London, pp: 56-66.

5. Difco Manual. 1984. Difco Manual of Dehydrated Culture Media and Reagents for Microbiological , Clinical and Laboratory Procedures. 10 $0^{\text {th }}$ Ed. Detroit, Mich., 48232 USA.

6. Eddouks, M., M. Maghrani, A. Lemhadri, M. L. Ouahidi and H. Jouad. 2002. Ethnopharmacological survey of medicinal plants used for the treatment of diabetes mellitus, hypertension and cardiac diseases in the South-East region of Morocco (Tafilalet). J. Ethnopharmacol., 82: 97-103.

7. Egyptian standard. 2005. Chilled fish. No. 3494, Egyptian Organization for Standardization and Quality Control, Ministry of Industry, Arab Republic of Egypt

8. GIAUC (Grupo de Investigacion en Acuicultura en la Universidad de Cantabria) 2006. Estudio de mercado: Demanda de filete de dorada en el mercado espa o̊l.Ministerio de Agricultura, Pesca y Alimentación. Madrid. C.F. Food Chemistry (2009) 114: 237-245.

9. Hernandez, M.D., M.B., Lo pez, A., Alvarez, E., Ferrandini, B.C. Garcia, and M.D. Garrido. 2009. Sensory, physical, chemical and microbiological changes in aquacultured meagre (Argyrosomus regius) fillets during ice storage. Food Chemistry, 114: 237-245.

10. Ibrahim, S. K. 2007. Antimicrobial and antioxidant effects of sodium acetate, sodium lactate, and sodium citrate in refrigerated sliced salmon. Food Control, 18: 566-575.

11. Jeon, Y.J, J. Y. V. A. Kamil and F. Shahidi. 2002. Chitosan as an edible invisible film for quality preservation of herring and Atlantic cod. Journal of Agricultural and Food Chemistry, 50 (18): 5167-5178.

12. Jeyasekaran, G., P. Ganesan, R., Anandaraj, Shakila and D. Sukumar. 2006. Quantitative and qualitative studies on the bacteriological quality of Indian white shrimp (Penaeus indicus) stored in dry ice. Food Microbiology, 23(6), 526-533. 
13. Kudi, A.C., J.U. Umoh, L.O. Eduvie and J. Gefu. 1999. Screening of some Nigerian medicinal plans for antibacterial activity. Journal of Ethnopharmacology, 67: 225228.

14. Loo, Y.H., P.S. Skell and H.N. Thornberry. 1945. Assay of Streptomycin by the paper disc plate method. J. Bacteriology, 50: 701-709.

15. Ojagh, S.M., M. Rezaei, S.H. Razavi and S.M. Hosseini. 2010. Effect of chitosan coatings enriched with cinnamon oil on the quality of refrigerated rainbow trout. Food Chemistry, 120: 193-198.

16. Palombo, E.A. and S.J. Semple. 2001. Antibacterial activity of traditional Australian medicinal plants. Journal of Ethnopharmacology, 77: 151-157.

17. Parekh, J. and S.V. Chanda. 2008. Antibacterial activity of aqueous and alcoholic extracts of 34 Indian medicinal plants against some staphylococcus species. Turkish Journal of Biology, 32: 63-71.

18. Patel, U., M., Kulkarni, V. Undale and A. Bhosale. 2009. Evaluation of diuretic activity of aqueous and methanol extracts of Lepidium sativum garden cress (Cruciferae) in rats. Tropical Journal of Pharmaceutical Research, 8 (3): 215-219.

19. Tidwell, J. H. and G. L. Allan. 2001. Fish as food: Aquaculture's contribution. EMBO Reports, 2 (11): 958-963. 


\section{خصائص الجودة الميكروبيولوجية لشرائح سمك قشر البياض المعامل بالمستخلص المائي لبذور حب الرشاد}

$$
\text { هناء عبد الفتاح عبد العزيز وعاطف سعد عبد المنعم عثيبة }
$$

قسم بحوث تكنولوجيا اللحوم والأسماك- معهد بحوث تكنولوجيا الأغذية- مركز البحوث الزراعية الجبيزة - مصر بكر

أجري هذا البحث بهذف التعرف على النشاط المضاد لنمو الميكروبات للمستخلص المائي والميثانولي لبذور حب الرشاد المحضر بتركيزات المختلفة (1، 2، 3 \%) لكل منهما حيث أجريت الدراسة على أربع سلالات من البكتريا السالبة لجرام ( Escherichia coli, E. coli 157, Salmonella وأربع سلالات أخري من البكتربا الموجبة لجرام (typhimurium and Kelbsiella pneumonia. Staphylococcus aureus, Bacillus subtilus, Bacillus megaterium, Listeria moncytogenes ) (serotype وسلالتين من الخمائر (Candida albican, and Sacchromyces cerevisiae) وسلالة فطر (Aspergillus niger). كذلك تم تقييم التركيزات المختلفة للمستخلص المائي لبذور حب الرشاد على

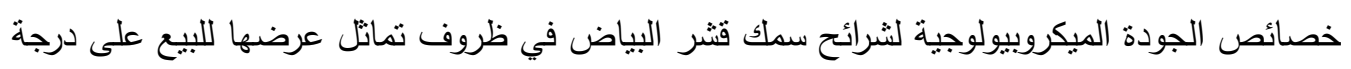
حرارة الغرفة وكذلك أثناء تخزينها بالتبريد على درجة حرارة 4 م حتى الفساد.

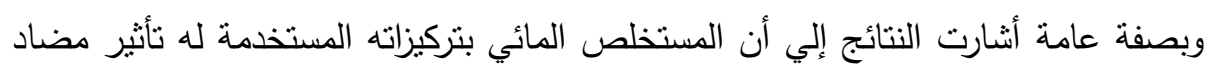

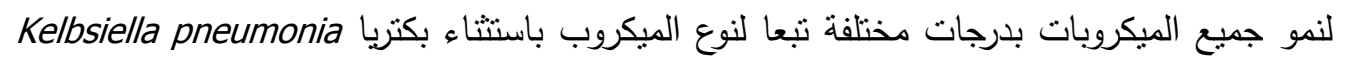

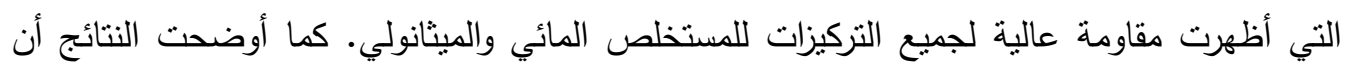
تركيز 1 و 2 \% من المستخلص الميثانولي له تأثثر مضاد لنمو جميع الميكروبات باستثناء البكتريا

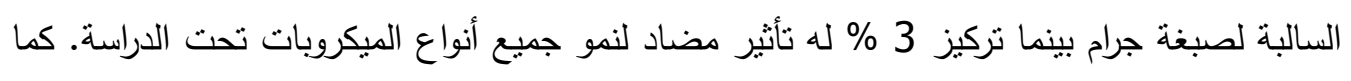

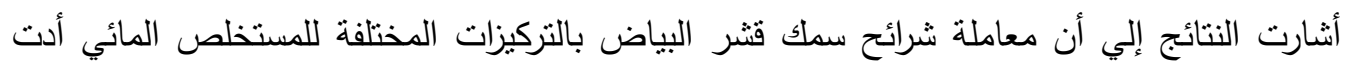
إلي تقليل الحمل الميكروبي وزيادة مدة صلاحيتها. 